\title{
Selected problems of RD-33 engine reliability in operation
}

\begin{abstract}
The paper presents an analysis of the most common damage incidents of the RD-33 turbine jet engine. Extended research on the assessment of powertrain reliability enabled a detailed identification of the causes of individual damage incidents along with possible threats. The presented statistical data related to the frequency of occurrence of individual damage incidents in recent years are particularly noteworthy. $R D-33$ is a newly designed engine, yet, in recent years it has gathered a very good opinion in the Polish Air Force, the effect of which are the efforts made by the military services and scientists aiming at the extending its proper and trouble free operation.
\end{abstract}

Key words: jet engine, powertrain, aircraft malfunction

\section{Wybrane problemy niezawodności eksploatacji silników RD-33}

W artykule zaprezentowano analize głównych uszkodzeń związanych z eksploatacją turbinowego silnika odrzutowego RD-33. Dlugoletnie badania zwiazane z ocena niezawodności zespołów napędowych umożliwity szczegółowa identyfikacje przyczyn powstawania poszczególnych uszkodzeń, wraz z wystęującymi zagrożeniami. Na szczególna uwage zastuguja przedstawione dane statystyczne związane z częstościa występowania poszczególnych rodzajów uszkodzeń w ostatnich latach. Silnik RD-33 nie należy do konstrukcji najnowocześniejszych, jednak w ciagu ostatnich lat zyskat w Sitach Zbrojnych RP bardzo dobra opinię, czego wynikiem sa prace podejmowane przez stużby wojskowe $i$ środowisko naukowe zmierzajace do wydtużenia jego prawidtowej i bezproblemowej eksploatacji.

Słowa kluczowe: silnik odrzutowy, zespót napędowy, uszkodzenia samolotu

\section{Introduction}

For many years we have been observing a rapid development of aviation powertrains technology whose most attention is focused on turbine engines. Modern turbine aircraft engines are very complex devices. Their technical parameters define the performance of the aircraft as well as the flight safety. The statistics related to the operation of all turbine aircraft engines indicate that if not for the ingress of foreign objects into the engine, a turbine engine could be deemed one of the most reliable components of a modern aircraft. This results from the application of the latest technologies of production of parts and subassemblies and the application of results of the latest scientific research that allow a design and selection of appropriate shapes of components such as the fan vanes. Turbine aircraft engines, however, still have their downsides and are not malfunction free. The analysis of reliability of aircraft in the Polish Air Force operated in the years 2009-2013 leads to a conclusion that $9 \%$ of aviation incidents was caused by engine malfunction, as shown in Fig. 1.

The above, spurs a question as to how to systematize the factors leading to the malfunction of turbine powertrains. A reduction of durability, reliability and efficiency of the turbine engines may be a result of the following reasons:

- design and production related reasons (adopted design solutions, type of material used for individual components),

- operation related reasons (manner of operation, conditions of the airstrips, fuel and lubricant quality),

\section{Wstęp}

Od wielu lat obserwuje się intensywny rozwój lotniczych technik napędowych, wśród których największa uwaga skupiona jest na turbinowych jednostkach napędowych. Współczesne turbinowe silniki lotnicze są obiektami o bardzo skomplikowanej budowie. Od ich parametrów pracy zależą osiągi statków powietrznych, a także bezpieczeństwo lotów. Statystyki dotyczące eksploatacji wszystkich obecnie lotniczych silników turbinowych wskazują, że gdyby nie uszkodzenia spowodowane zasysaniem ciał obcych, silnik turbinowy można by uznać za najbardziej niezawodny element współczesnego samolotu. Wynika to ze stosowania najnowszych technologii wytwarzania części i podzespołów oraz wykorzystania wyników najnowszych badań naukowych, które umożliwiają projektowanie i dobór odpowiednich kształtów elementów, np. łopatek. Jednak nie zmienia to faktu, że turbinowe silniki lotnicze nie są pozbawione wad i nie ulegają uszkodzeniom. Analiza niezawodności statków powietrznych eksploatowanych w Siłach Zbrojnych RP w latach 2009-2013 pozwala stwierdzić, że $9 \%$ zdarzeń lotniczych spowodowanych było uszkodzeniami silników, co przedstawia rys. 1.

Pojawia się więc pytanie, w jaki sposób można usystematyzować czynniki powodujące uszkodzenia turbinowych zespołów napędowych. Zmniejszenie trwałości, niezawodności, a także efektywności użycia turbinowych silników lotniczych może występować w wyniku pojawienia się następujących uwarunkowań: 
- mechanical reasons (thermal or mechanical loads),

- climate related reasons (humidity, temperature, hail).

In recent years, in the Polish Air Force majority of the aviation incidents pertained to the RD-33 engines used on the MiG-29 aircraft, which is why the paper discusses the significant aspects of problems related to the failure of these engines.

Serial production of the RD-33 engine began in 1981. This is a low by-pass rate turbo fan engine fitted with an afterburner. Figure 2 presents the cross-section of the RD33 engine built from a 4 stage low-pressure compressor, 9 stage high-pressure compressor, a ring combustor, 1 stage low-pressure turbine, 1 stage high-pressure turbine common

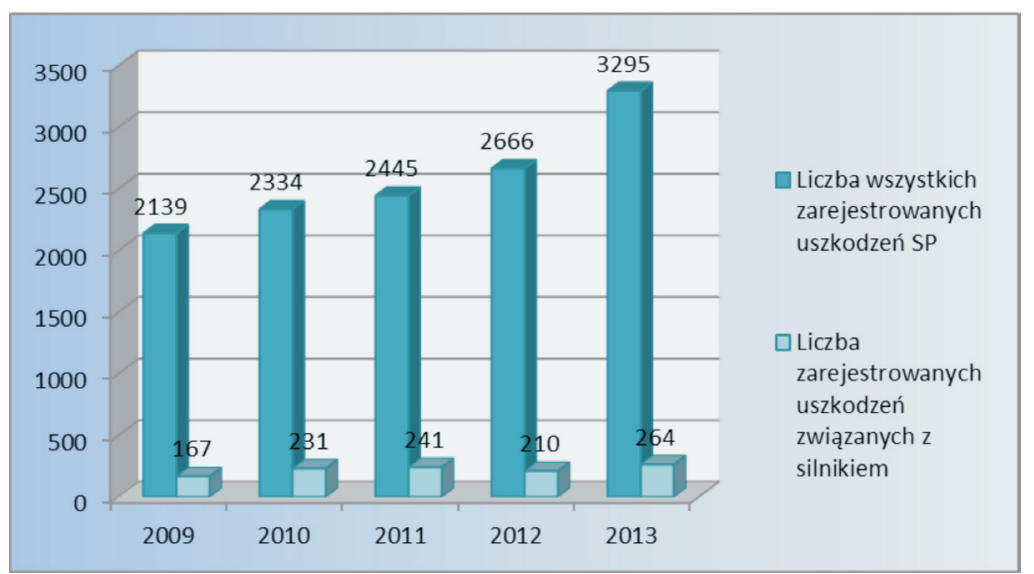

Fig. 1. Number of aircraft incidents related to the malfunctioning powertrain in the Polish Air force in the years 2009-2013

Rys. 1. Liczba uszkodzeń statków powietrznych związanych z niesprawnościa zespołów napędowych w Siłach Zbrojnych RP w latach 2009-2013

for both external and internal passages of the combustor and an adjustable propelling nozzle.

Despite initial pre-production prototype problems, the above-mentioned powertrain, upon detailed improvements, turned out very successful. Its advantage is a very simple design and relatively low fuel consumption. The MiG-29 fighter plane fitted with two RD-33 engines produces a very high maximum speed in both the horizontal and ascending flight, let alone high acceleration, very useful in direct combat. MiG-29 is capable of obtaining a maximum vertical ascending rate of approx. $330 \mathrm{~m} / \mathrm{s}$.
- konstrukcyjnych i produkcyjnych (np. przyjęte rozwiązania konstrukcyjne, rodzaj materiału poszczególnych podzespołów),

- eksploatacyjnych (np. sposób eksploatacji, stan powierzchni lotniskowych, czy jakość paliw i smarów),

- mechanicznych (np. obciążenia termiczne lub mechaniczne),

- klimatycznych (np. wilgotność, temperatura, opady gradu).

W ciągu ostatnich kilku lat w lotnictwie Sił Zbrojnych RP znaczna część zdarzeń lotniczych dotyczyła silników RD-33, eksploatowanych na samolotach MiG-29, dlatego w artykule tym omówiono najważniejsze aspekty problemów związanych z zawodnością tych silników.

Silnik RD-33 jest konstrukcją, której seryjną produkcję rozpoczęto w $1981 \mathrm{r}$. Jest to turboodrzutowy, dwuprzepływowy silnik z dopalaczem, w którym dwuprzepływowość występuje w małym stopniu. Na rysunku 2 przedstawiono przekrój silnika RD-33, który zbudowany jest z czterostopniowej sprężarki niskiego ciśnienia, dziewięciostopniowej sprężarki wysokiego ciśnienia, pierścieniowej komory spalania, jednostopniowej turbiny niskiego ciśnienia, jednostopniowej turbiny wysokiego ciśnienia wspólnej dla kanałów przepływu zewnętrznego i wewnętrznego komory dopalacza oraz regulowanej dyszy wylotowej.

Pomimo początkowych problemów w przedseryjnych prototypach, wyżej wymieniony układ napędowy po drobiazgowej korekcji okazał się bardzo udany. Jego zaletą jest bardzo prosta konstrukcja oraz stosunkowo małe zużycie paliwa. Myśliwiec MiG-29 wyposażony w dwa silniki RD-33 uzyskał dużą prędkość maksymalną zarówno w locie poziomym, jak i podczas wznoszenia, a także ogromne przyśpieszenie, bardzo przydatne w bezpośrednim starciu. MiG-29 jest w stanie osiągnąć maksymalną pionową prędkość wznoszenia równą ok. $330 \mathrm{~m} / \mathrm{s}$.

\section{Uszkodzenia silników RD-23 związane z zasysaniem cial obcych}

Największym problemem związanym z eksploatacją turbinowych silników odrzutowych lotnictwa państwowego

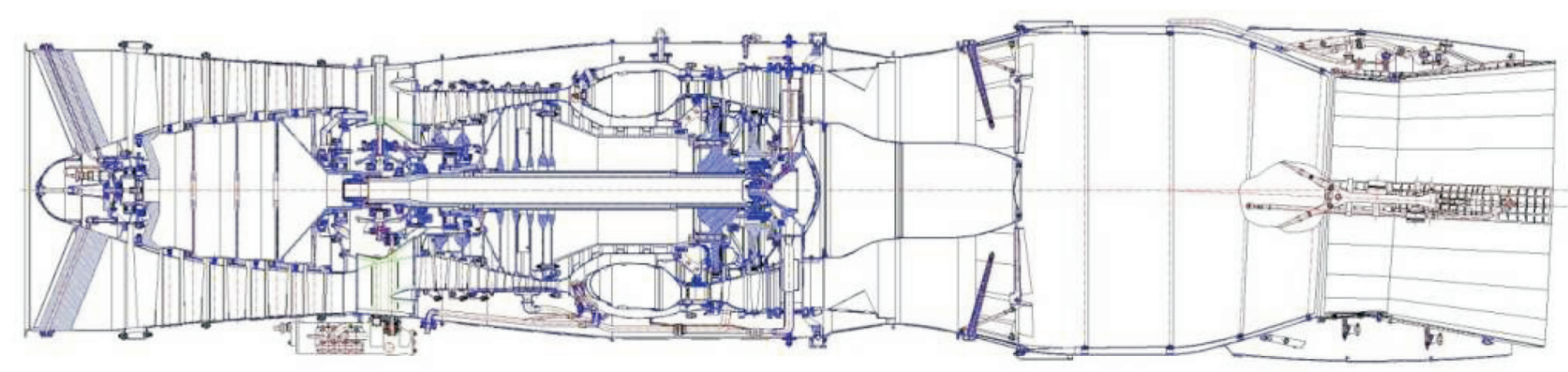

Fig. 2. RD-33 engine cross-section

Rys. 2. Przekrój silnika RD-33 


\section{RD-23 damage related to the ingress of foreign objects}

The biggest problem related to the operation of turbine jet engines used in general and military aviation is the ingress of foreign objects. This is mainly related to the design of the engine and its location in the aircraft. The incidents can be divided into two groups:

1) damage of a turbine engine by loose elements, particles and objects on the aircraft path during flight or when stationary,

2) damage of a turbine engine following an ingress of a bird during flight.

The ingress of foreign objects to the engine (e.g. chunks of concrete, ice, snow or parts of other planes and vehicles) may take place during taxi runway acceleration and takeoff. The highest number of incidents involving bird ingress into the engine takes place in the springtime, at the end of summer and beginning of autumn on the height of up to $15 \mathrm{~m}$ [1].

The engine components of the highest exposure to foreign objects ingress are the vanes of the low and high-pressure compressor. Damage of the fan vanes results in a change of the distribution of the mass forces and unbalancing, which may lead to a serious increase in the engine vibration, detachment of a vane and, eventually, even seizure of the rotor shaft. It is quite easy to understand why it happens that way - in a properly operating engine the circumferential velocity of the vanes of the first stages of the compressor at their tips may exceed $500 \mathrm{~m} / \mathrm{s}$. [3]. Fig. 3 presents example images of the vanes of RD-33 engines retrieved from the aircraft in service.

The MiG-29 fighter plane has two intake diffusers under the wings that ensure maximum thrust efficiency and proper operation on all flight stages. In order to prevent foreign objects from getting into the engine when the plane is grounded, the intake channels are covered with front moving flaps and the air gets through the upper intake in the upper part of the fuselage. This solution significantly reduces the number of incidents of foreign object ingress related damage. The problem, however, has not yet been entirely eliminated.

The analysis of data from Fig. 4 indicates that FOD (foreign object damage) still occurs. The positive aspect is that fact that in the passing years one can see a diminishing trend of the flight incidents. This also pertains to cases in which the vanes were regenerated by the Air Force Institute of Technology (ITWL), where one of the methods is the smoothing of the damaged surfaces by their polishing. Engines cleared for further operation are constantly monitored. Figure 5 presented a comparison before and after the correctional polishing. In the 23 Tactical Air Base (BLT) in the years 2008-2015, 16 engines were in service, in which such damage of the vanes was identified that allowed their regeneration by polishing. i cywilnego jest zasysanie ciał obcych. Związane jest to przede wszystkim z samą budową silnika, a także z usytuowaniem go na statku powietrznym. Zdarzenia te można podzielić na dwie grupy:

1) uszkodzenie silnika turbinowego przez elementy, cząstki i przedmioty luźno znajdujące się na powierzchniach dróg podczas przemieszczania się czy postoju samolotu,

2) uszkodzenie silnika turbinowego przez zassanie ptaka podczas lotu samolotu.

Dostawanie się ciał obcych do silnika (np. kawałki betonu, lód, śnieg czy elementy konstrukcyjne innych samolotów i pojazdów) może odbywać się podczas kołowania, rozbiegu i startu samolotu. Najwięcej natomiast incydentów z udziałem ptaków zachodzi podczas lotów wiosną, pod koniec lata i na początku jesieni, na wysokości do $15 \mathrm{~m}$ [1].

Elementem silnika najbardziej narażonym na oddziaływanie zasysanych ciał obcych są łopatki sprężarki niskiego i wysokiego ciśnienia. Uszkodzenie łopatek roboczych wentylatora powoduje zmianę rozkładu sił masowych, pojawienie się niewyważenia, co może doprowadzić do znacznego wzrostu poziomu drgań silnika, urwania łopatki, a w ostateczności nawet do zablokowania pędni wirnika. Nietrudno jest zrozumieć, dlaczego tak się dzieje: w poprawnie działającym silniku prędkość obwodowa łopatek pierwszych stopni sprężarki na ich wierzchołkach może przekraczać 500 $\mathrm{m} / \mathrm{s}$. [3]. Na rysunku 3 przedstawiono przykładowe zdjęcia łopatek silnika RD-33 wymontowanych z eksploatowanych samolotów.

Samolot MiG-29 ma dwa podskrzydłowe dyfuzory wlotowe, które zapewniają maksymalną efektywność ciągu i prawidłową pracę na wszystkich zakresach lotu. Aby uniemożliwić wpadanie ciał obcych do silnika, podczas pracy samolotu na ziemi, kanały dyfuzorów wlotowych zamknięte są przednimi ruchomymi płytami, a powietrze do silników w tym przypadku dopływa przez klapy górnego wlotu, znajdujące się w górnej części kadłuba. Rozwiązanie

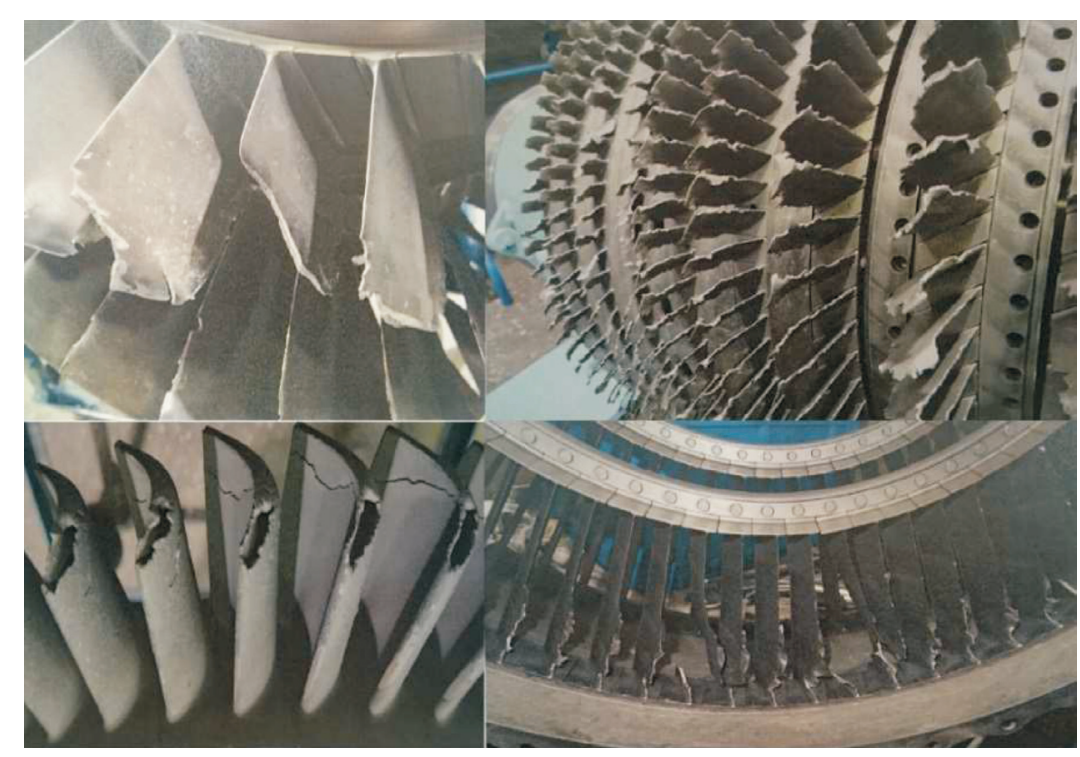

Fig. 3. Compressor vanes of the RD-33 engine upon ingress of a foreign object Rys. 3. Stan łopatek sprężarki silnika RD-33 po zassaniu ciała obcego 


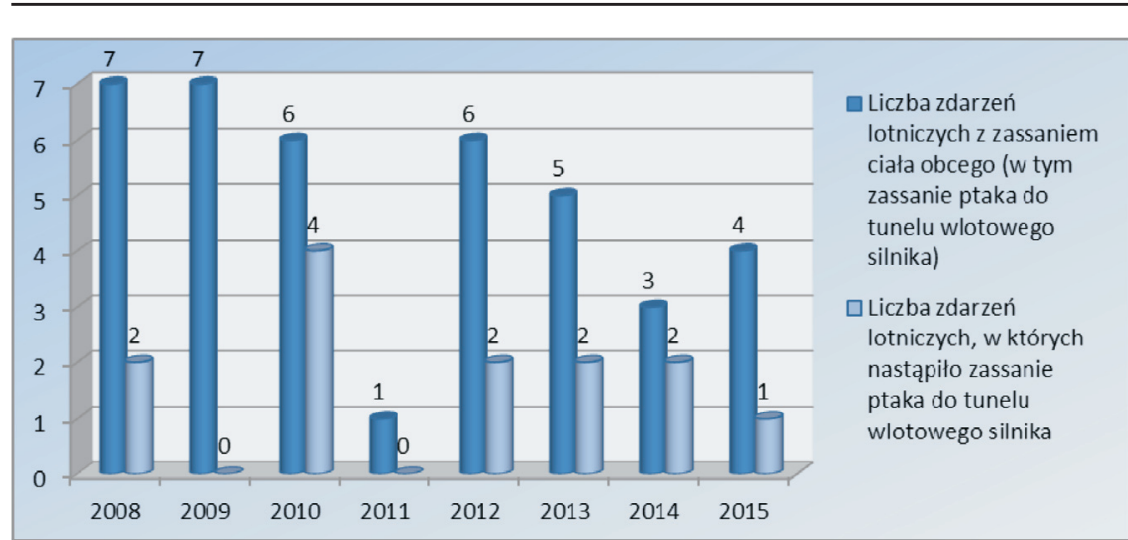

Fig. 4. Number of incidents of RD-33 engine damage related to the ingress of a foreign object in the Polish Air Force in the years 2008-2015

Rys. 4. Liczba uszkodzeń silników RD-33 związanych z zassaniem ciała obcego w Siłach Zbrojnych $R P$ w latach 2008-2015

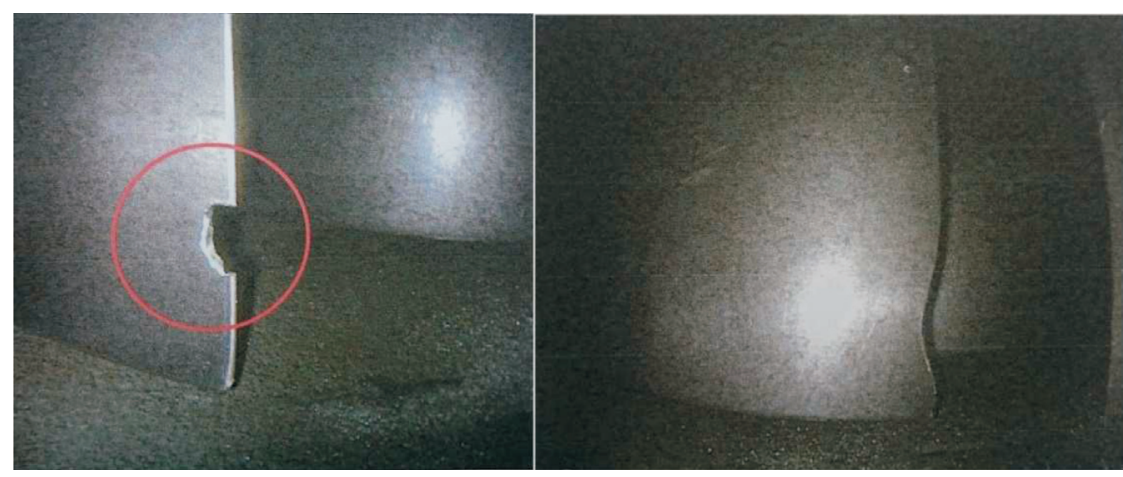

Fig. 5. Comparison of the fan vanes of the RD-33 engine before and after polishing Rys. 5. Porównanie topatek wentylatora silnika RD-33 przed i po szlifowaniu

\section{Damage to the vanes of the high-pressure turbine in the RD-33 engines}

Another problem that significantly influences the operation of RD-33 engines are incidents related to the damage of the high-pressure turbine. A direct cause of this type of malfunction is thermal loads of the hot part of the engine. Despite the fact that each component of the RD-33 engine is designed to ensure a stable operation in the entire work range, certain disadvantageous factors lead to the occurrence of conditions other than the design ones that may lead to engine damage. Figure 6 presents the levels of malfunction related to the damage of the RD-33 engine turbine in the 23 Tactical Airbase (BLT) in the years 2007-2015. Analyzing the presented data one may observe that an average annual number of engines withdrawn from operation reaches approx. 13\%.

The most frequent damage is:

- cracks at the cutting edge of the vanes of the high-pressure turbine,

- degradation of the surface layer of the vanes of the highpressure turbine with areas of surface chipping,

- local burnouts of the core material of the vanes,

- cracks of the variable geometry vanes of the high-pressure turbine,

- burnout of the variable geometry vanes of the low-pressure turbine. to w znaczny sposób obniżyło liczbę uszkodzeń silników przez zassanie ciała obcego. Jednakże problem ten nie został całkowicie rozwiązany.

Analiza danych z rys. 4 wskazuje, że nadal zdarzają się uszkodzenia silników zakwalifikowanych jako FOD (Foreign Object Damage). Pozytywnym aspektem jest to, że w mijających latach widać tendencję do zmniejszania się liczby tych zdarzeń lotniczych. Dotyczy to również łopat regenerowanych przez Instytut Techniczny Wojsk Lotniczych (ITWL), gdzie jednym ze sposobów jest wygładzanie uszkodzonych powierzchni przez ich szlifowanie. Silniki dopuszczone do dalszej eksploatacji, eksploatowane są pod stałym dodatkowym nadzorem. Na rysunku 5 przedstawiono porównanie łopatek przed i po szlifowaniu korygującym. W 23. Bazie Lotnictwa Taktycznego (BLT) w latach 2008-2015 eksploatowano 16 silników, w których wykryto uszkodzenia łopatek pozwalających na ich regeneracje przez szlifowanie.

\section{Uszkodzenia lopatek turbiny wysokiego ciśnienia silników RD-33}

Innym problemem, który znacząco wpływa na eksploatację silników RD-33 są zdarzenia polegające na uszkodzeniach turbiny wysokiego ciśnienia. Bezpośrednią przyczyną tego typu niesprawności są znaczne obciążenia cieplne gorącej części silnika. Pomimo że każdy element silnika RD-33 jest zaprojektowany tak, aby zapewnić stabilne jego działanie w całym zakresie pracy, pewne niekorzystne czynniki powodują pojawianie się warunków innych niż projektowe, które mogą doprowadzić do uszkodzenia silnika. Na rysunku 6 przedstawiono poziomy niesprawności związanych z uszkodzeniem turbiny silnika RD-33 w 23. BLT w latach 2007-2015. Analizując przedstawione dane, można stwierdzić, że rocznie średnio ok. 13\% silników jest wycofywanych z eksploatacji.

Najczęściej pojawiające się uszkodzenia to:

- pęknięcia na krawędzi natarcia łopatek wirnika turbiny wysokiego ciśnienia,

- degradacja warstwy wierzchniej łopatek turbiny wysokiego ciśnienia z obszarami łuszczenia się tej warstwy,

- miejscowe wypalenia materiału rdzenia łopatek,

- pęknięcia łopatek kierowniczych turbiny wysokiego ciśnienia,

- wypalenia łopatek kierownicy turbiny niskiego ciśnienia.

Na rysunku 7 przedstawiono najczęstsze uszkodzenia łopatek turbiny wysokiego ciśnienia w silniku RD-33. 


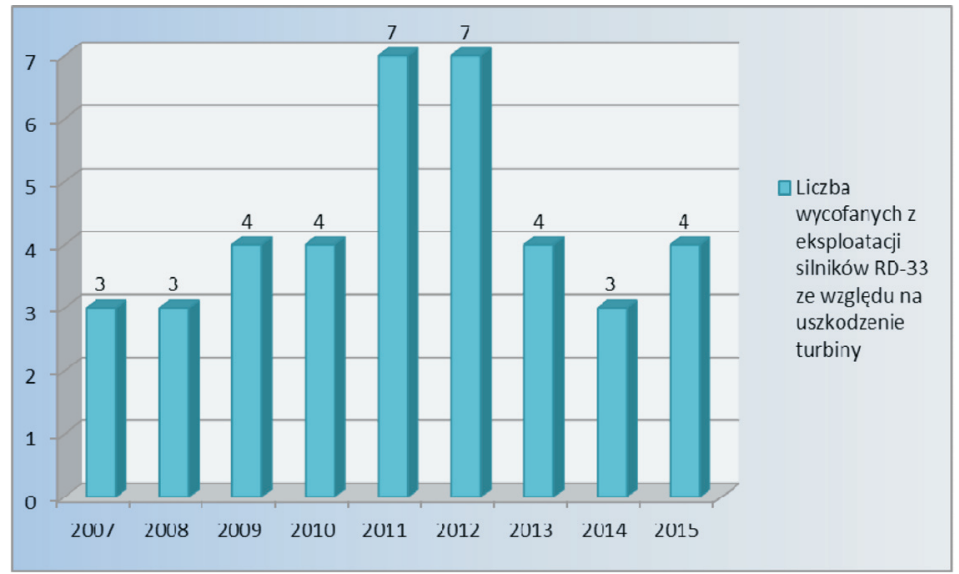

Fig. 6. The number of RD-33 engines withdrawn from operation due to the damage of the high-pressure turbine in the 23 BLT in the years 2007-2015

Rys. 6. Liczba wycofanych z eksploatacji silników RD-33 ze względu na uszkodzenie turbiny wysokiego ciśnienia w 23. BLT w latach 2007-2015

Figure 7 presents the most frequent damage of the highpressure turbine vanes of the RD-33 engine.

The most sensitive component of the RD-33 engine is the high-pressure turbine. The reasons for its damage may vary. Among the users of the MiG-29 fighter planes in Poland there is a common opinion that it is the improper overhaul of the high-pressure turbine (its vanes) that is the source of the operational issues. Scientific sources, however, present an entirely different conclusion related to this problem. For the sake of the explanation of the reasons for the vane cracking of the RD-33 engine high-pressure turbine no. 870881972265 , Air Force Institute of Technology has carried out investigations. In the conclusions contained in [2], it has been stated that:

- all vanes of the high-pressure turbine were damaged in the form of cracks caused by fatigue loads occurring in the spots of erosion-corrosion defects of the surface,

- increased thermal load of the vane cutting edge was most likely a facilitator of the crack initiation,

- no direct relation of the erosion-corrosion wear of the vane cutting edge with the crack initiation was confirmed.

In [2] attention was drawn to the fact that the condition of the protective layer of the damaged vanes was fine. From the above, it results that the theory, however unpopular among the RD-33 engine users, that the vane overheating is largely responsible for the degradation of the surface layer of the high-pressure turbine vanes and its cracking, is substantiated with sufficient proof. Vane overheating may take place in three ways:

- following an excess exhaust gas temperature downstream of the engine turbine (t4),

- as a result of improper combustion of the air-fuel mixture during regular engine operation,
Najbardziej newralgicznym elementem silnika RD-33 jest turbina wysokiego ciśnienia. Przyczyny jej uszkodzenia mogą być różne. Wśród użytkowników samolotów MiG-29 w Polsce panuje przekonanie, że to niewłaściwy remont turbiny wysokiego ciśnienia, a dokładniej jej łopatek jest przyczyną ww. problemów eksploatacyjnych. Jednak zupełnie inne wnioski dotyczące tego zagadnienia zawarte są w opracowaniach naukowych. Na potrzeby wyjaśnienia przyczyn pęknięcia łopatek turbiny silnika RD-33 nr 870881972265 Instytut Techniczny Wojsk Lotniczych przeprowadził badania. We wnioskach z badań, zwartych w opracowaniu [2], stwierdzono, że:

-wszystkie badane łopatki turbiny wysokiego ciśnienia uległy uszkodzeniom w postaci pęknięć z powodu występowania obciążeń zmęczeniowych w miejscach pojawiania się defektów erozyjno-korozyjnych powierzchni,

-zwiększone obciążenie termiczne krawędzi natarcia łopatek prawdopodobnie było czynnikiem sprzyjającym inicjacji pęknięć,

- nie potwierdzono bezpośredniego związku zużycia erozyjno-korozyjnego powierzchni krawędzi natarcia łopatek $\mathrm{z}$ inicjacją pęknięć.

Ponadto w opracowaniu [2] zwrócono uwagę, że stan powłoki ochronnej uszkodzonych łopatek turbiny nie budzi zastrzeżeń. Wynika stąd, że niepopularna wśród użytkowników silników RD-33 teza, iż to przegrzanie łopatek w znacznym stopniu jest powodem degradacji warstwy wierzchniej łopatek turbiny wysokiego ciśnienia oraz ich pęknięć, ma swoje uzasadnienie podparte dowodami. Przegrzanie łopatek może następować w trojaki sposób:

- w wyniku przekroczenia dopuszczalnej podczas eksploatacji temperatury spalin za turbiną silnika (t4),

- w wyniku nieprawidłowego procesu spalania mieszanki paliwowo-powietrznej podczas prawidłowej eksploatacji silnika,

- w wyniku wzrostu strumienia gęstości ciepła wnikającego w okolicy krawędzi natarcia oraz spływu, będącego efektem wzrostu współczynnika wnikania ciepła.

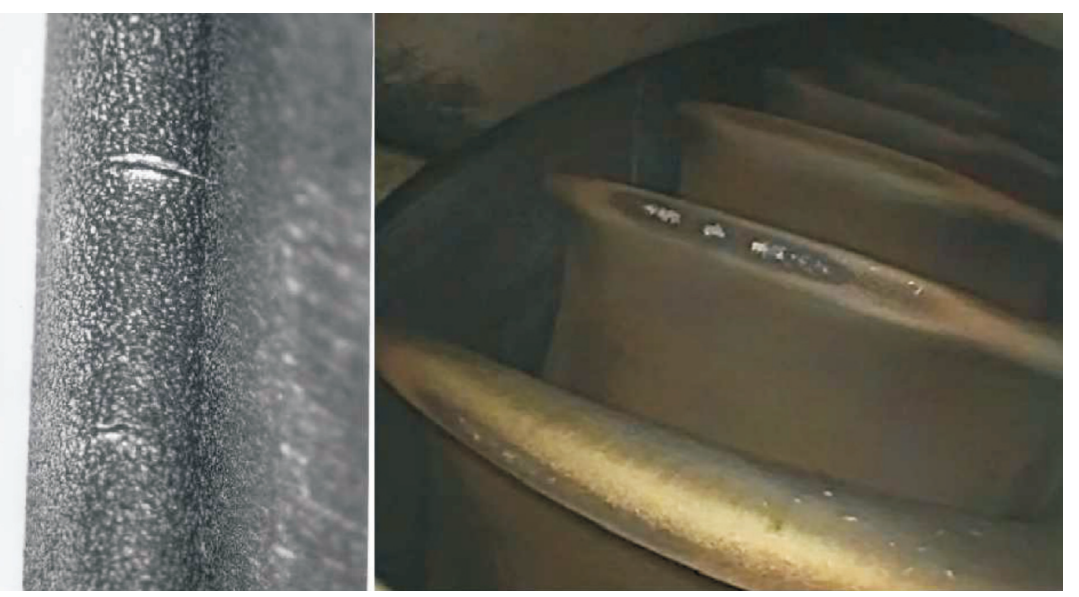

Fig. 7. Examples of damage to the high-pressure turbine vanes of the RD-33 engine Rys. 7. Przykłady uszkodzeń topatek turbiny wysokiego ciśnienia silnika RD-33 
- as a result of an increase of the heat flow density conducted in the area of the cutting edge of the vane, being the result of the increase of the heat conductance.

The excess of admissible exhaust gas temperature $t 4$ can be avoided through appropriate pilot training and engineering services (SIL) but the second cause is a more complex one. Based on [4] it has been confirmed that the reason for improper combustion is the distortion of the fuel atomization process. This results in a shift of the flame in the combustor, which leads to an increased temperature in the turbine zone where usually there is no risk of excess thermal load under typical combustion conditions. This is most likely caused by the physicochemical properties of the F-34 jet fuel, used to power MiG-29 engines. Even though this fuel meets all standard requirements, it is a fact that the tested fuel samples showed an increased content of resins. The presence of this component may indirectly lead to the formation of carbon deposits on the injectors and a distortion of the atomization process.

To sum up, the problem of high-pressure turbine damage is a complex one, yet, based on the available works it is known that it is not the quality of the repair but a variety of other conditions occurring independently of the user that are responsible for the damage. It is a substantiated assumption to say that the turbine vane damage will continue occurring as long as the RD-33 engines are operated under unmodified terrain and technical conditions.

\section{Damage of the rotor discs of the RD-33 engine fans}

A new issue that has come up recently in the Polish Armed Forces during the operation of the MiG-29 planes is the damage of the rotor discs of the RD-33 engine fans. At the end of 2013 on two different MiG-29 planes incidents took place that were investigated by the State Commission on Aircraft Accident Investigation (KBWL LP). Based on the Commission conclusions, following the investigations, it was confirmed that the cause of the damage of both tested engines was the exceeded fatigue limit of a disc of the IV stage of the fan, the result of which was its cracking. Figure 8 presents the examples of the damage of the rotor discs of the RD-33 engine.

In the first plane the damage was a result of the rubbing of the disc labyrinth of the IV stage of the fan against the labyrinth of its guiding element, and in the second plane the damage was caused by the fan vane shot through the gas channel of the engine.

Based on the repair documentation and following the engine disassembly, it has been observed that the fans fitted in the engines were of the type 330118220 whose total maintenance free operating period (MFOP) was extended from 1200 to 1600 hours during the overhaul performed at the manufacturer's works in the Russian Federation. It is noteworthy that both engines had an extended MFOP to 1600 hours at the time when their user was the German Air Force.

State Commission on Aircraft Accident Investigation has ascertained that there are three types of fan rotors fitted in the RD-33 engines:
O ile przekroczeń dopuszczalnej temperatury spalin $t 4$ można uniknąć przez szkolenia personelu latającego i Służb Inżynieryjno-Lotniczych (SIL), o tyle druga przyczyna ma bardziej skomplikowane podłoże. Na podstawie opracowania [4] stwierdzono, że przyczyną nieprawidłowego spalania jest zaburzenie procesu rozpylania paliwa. Powoduje to przesunięcie płomienia w komorze spalania, przez co może wzrastać temperatura w strefie turbiny, czyli w miejscu, gdzie przy prawidłowym spalaniu nie ma narażenia na zwiększone obciążenia cieplne. Spowodowane jest to prawdopodobnie właściwościami fizykochemicznymi paliwa lotniczego F-34, używanego w eksploatacji samolotu MiG-29. Choć paliwo to spełnia wszystkie wymagania normatywne, to stwierdzono, że przebadane próbki paliwa mają podwyższoną zawartość żywic. Obecność tego składnika w pośredni sposób może powodować powstawanie nagaru na wtryskiwaczach, a w rezultacie tego zaburzenia procesu rozpylania paliwa.

Reasumując, problem uszkodzeń turbiny wysokiego ciśnienia jest złożony, lecz na podstawie dostępnych opracowań można stwierdzić, że to nie jakość remontu jest za uszkodzenia odpowiedzialna, lecz wiele innych uwarunkowań, w większości niezależnych od użytkownika. Uzasadniona jest teza, że uszkodzenia łopatek turbiny będą występować dopóty, dopóki eksploatowane będą silniki RD-33 w dotychczasowych warunkach terenowych i technicznych.

\section{Uszkodzenia tarcz wirników wentylatorów silników RD-33}

Nowym problemem, który pojawił się w ostatnim czasie w Siłach Zbrojnych RP podczas eksploatacji samolotów MiG-29, są uszkodzenia tarcz wirników wentylatorów silników RD-33. Pod koniec 2013 r. na dwóch różnych samolotach MiG-29 miały miejsce zdarzenia, które badała Komisja Badania Wypadków Lotniczych Lotnictwa Państwowego (KBWL LP). Na podstawie ustaleń, wynikających z przeprowadzonych badań, stwierdzono, że przyczyną uszkodzenia obydwu badanych silników było przekroczenie trwałości zmęczeniowej tarczy IV stopnia wentylatora, w wyniku czego uległa ona pęknięciu. Na rysunku 8 przedstawiono przykłady uszkodzenia tarcz wirników silnika RD-33.

Na pierwszym samolocie uszkodzenia były wynikiem ocierania labiryntu tarczy IV stopnia wentylatora o labirynt jego aparatu kierującego, na drugim - uszkodzenie spowodowała łopatka wentylatora, przemieszczającą się kanałem gazowym silnika.

Na podstawie dokumentacji remontowej oraz wyników komisyjnego demontażu stwierdzono, że na przedmiotowych silnikach zabudowane były wentylatory typu 330118220 , których resurs całkowity został zwiększony z 1200 do 1600 godz. podczas remontów wykonanych w zakładzie producenta w Federacji Rosyjskiej. Warto odnotować, że oba silniki miały zwiększany resurs techniczny do 1600 godzin w momencie, gdy ich użytkownikiem były Niemieckie Siły Powietrzne.

Komisja Badania Wypadków Lotniczych LP ustaliła, że w silnikach RD-33 występują trzy typy wirników wentylatora: 
- 330118140 - the oldest used before 1986,

- 330118220 - fitted from 1986 onward,

- 330118280 - fitted in engines from engine number 870882972104 onward and equipped with reinforced discs in the I-IV stage.

As of the moment of the tests, the testing technicians were disturbed by the fact that both damaged engines had a similar uptime of approx. 1320 hours, which indicated repeatability of the incident. In order to prevent further incidents caused by the fan rotor cracking in the MiG-29 planes a procedure of establishing of a unified MFOP of the fan rotor was introduced. It has been ascertained that the RD-33 engines are to be in service until the rotors have reached the following uptime:

- fan rotor 330118140 - 1000 hours,

- fan rotor 330118220 - 1200 hours,

- fan rotor $330118280-1600$ hours.

The analysis of the rotor types fitted in the RD-33 engines operated by the Polish Air Force has indicated that part of the engines were to be immediately withdrawn from operation due to the excess of the newly adopted MFOP. In the 23 BLT as many as 7 RD-33 engines had to be withdrawn from further operation. The WZL-4 S.A. Repair Works has also been subjected to supervision where changes to the repair procedures were introduced forcing the performance of nondestructive tests of the discs of all fan stages. The previously applicable documentation recommended a non-destructive inspection of the discs of the I stage exclusively.

Figure 9 presents the percentage division of RD-33 engines into individual fan rotor types currently used in the Polish Armed Forces.

The presented data show that approx. $30 \%$ of the RD33 engines used in the Polish armed forces are fitted with rotors of the older generation. In order to fully exploit their technical life cycle and be certain that similar malfunctions will not recur in the MiG-29 fighter planes, the 330118140

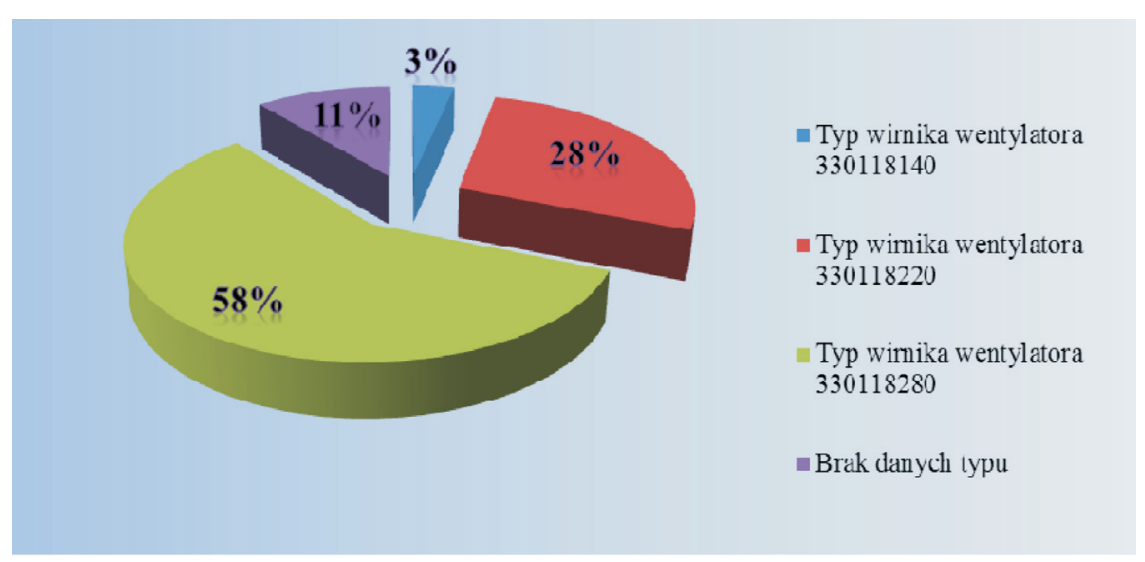

Fig. 9. Percentage division of RD-33 engines into individual fan rotor types in service in the Polish Armed Forces (as at 10.01.2016)

Rys. 9. Procentowy podział silników RD-33 na poszczególne typy wirnika wentylatora $w$ Siłach Zbrojnych RP (stan na 10.01.2016 r.)
- zespół 330118140 - najstarszy, stosowany przed 1986 r., - zespół 330118220, montowany na silnikach od 1986 r.,

- zespół 330118280, montowany na silnikach od numeru 870882972104 i wyposażony we wzmocnione tarcze I-IV stopnia.

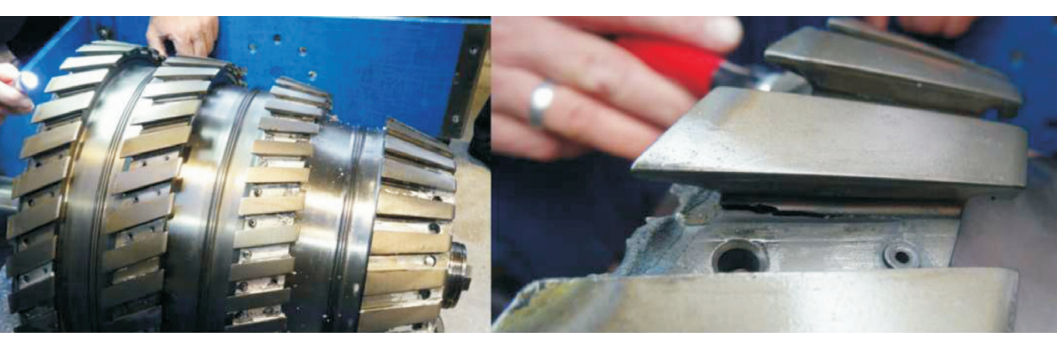

f a fatigue crack of the discs of the IV stage of the RD-33 engine fan (on the left- view of the entire rotor, on the right - visible crack) lewej - widok catego wirnika, po prawej-widoczne pęknięcie)

W momencie badania niepokój wzbudziło to, że oba uszkodzone silniki miały podobny czas pracy od początku eksploatacji, wynoszący ok. 1320 godzin, co wskazywałoby na powtarzalność zdarzenia. W celu zapobiegnięcia kolejnym wypadkom lotniczym spowodowanym pękaniem wirnika wentylatora, na samolotach MiG-29 wdrożono procedurę jednoznacznego ustalenia wielkości resursu technicznego wirnika wentylatora. Ustalono, że silniki RD-33 należy eksploatować do wypracowania przez wirniki wentylatorów następujących wartości resursu od początku eksploatacji: - z wirnikiem wentylatora typu 330118140 - 1000 godz., - z wirnikiem wentylatora typu 330118220 - 1200 godz., - z wirnikiem wentylatora typu 330118280 - 1600 godz..

Analiza typów wirników zabudowanych na silnikach RD-33 znajdujących się w Siłach Zbrojnych RP wskazała, że część silników należało natychmiast wycofać z eksploatacji, W związku z przekroczeniem nowo przyjętych resursów technicznych. W 23. BLT należało wstrzymać od dalszej eksploatacji aż 7 silników RD-33. Nadzorem objęto także zakład remontowy WZL-4 S.A., gdzie wprowadzono zmiany do procedury remontu, nakazujące przeprowadzenie badań nieniszczących tarcz wszystkich stopni wentylatora. Wcześniej obowiązująca dokumentacja producenta polecała kontrolę metodami nieniszczącymi tylko tarczy I-go stopnia.

Na rysunku 9 przedstawiono procentowy podział silników RD-33 z podziałem na poszczególne typy wirnika wentylatora, aktualnie stosowane w Siłach Zbrojnych RP.

Przedstawione dane wskazują, że ok 30\% silników RD-33 w Siłach Zbrojnych RP posiada wirniki starszego typu. Aby móc w pełni wykorzystywać ich resurs techniczny oraz mieć pewność, że podobne awarie nie pojawią się na 
and 330118220 fans should be gradually eliminated and renewed with the more reliable 330118280 during repairs and modernizations of the RD-33 engines.

\section{Conclusions}

The increasing safety-related costs of operation of the RD-33 engines are attributed to the increasing level of reliability of powertrain diagnostics and monitoring. It forces an increased accuracy of determination of the technical condition of individual engine aggregates and determination of their durability. The examples presented in the paper confirm the assumption that proper understanding of the causes of malfunctions allows an extension of the period of safe operation of the MiG-29 fighter planes. Sometimes, as shown in chapter 3, a proper identification of a threat does not directly result in a reduction of the frequency of its occurrence. Proper proactive behavior after each incident may significantly improve the flight safety, as presented in chapter 4 . As per the principle of collaboration and synergy, full functionality of the system of operation and maintenance of RD-33 engines may be achieved owing to a direct or indirect support of the service operations by the engine manufacturer. Unfortunately, the absence of efforts of the Polish repair facilities related to the certification regarding engine overhauls, hence no access to the ever-changing engine operational strategies, ensues serious problems in the RD-33 engine operational management. The decreasing engine operational potential resulting from a lack of its standardization, causes serious operational issues that will need to undergo transformations following substantive managerial decisions. samolotach MiG-29, należy podczas realizacji remontów i usprawnień silników RD-33 stopniowo eliminować wentylatory typu 330118140 oraz 330118220 i zastępować je bardziej niezawodnymi typu 330118280.

\section{Podsumowanie}

Wzrost kosztów eksploatacji silników RD-33 związanych z bezpieczeństwem wiąże się z podnoszeniem poziomu wiarygodności diagnostyki i kontroli zespołu napędowego. Wymusza on zwiększenie dokładności określenia stanu technicznego agregatów silnika turbinowego celem określenia ich trwałości. Przykłady przedstawione w artykule potwierdzają tezę, że właściwe zrozumienie przyczyn wywołujących niesprawności umożliwia wydłużenie okresu bezpiecznej eksploatacji samolotu MiG-29. Czasami, jak to przedstawiono w rozdz. 3, właściwa identyfikacja zagrożenia nie skutkuje w sposób bezpośredni obniżeniem częstotliwości jego występowania. Niemniej jednak, właściwa profilaktyka po każdym zdarzeniu lotniczym może znacznie poprawić bezpieczeństwo latania, co przedstawiono w rozdz. 4. Zgodnie z zasadą kooperacji i synergii, pełna funkcjonalność systemu eksploatacji i obsługi silników RD-33 może być osiągnięta dzięki wsparciu bezpośredniemu lub pośredniemu procesu obsług przez producenta silników. Niestety, brak starań o certyfikację ze strony polskiego zakładu remontowego w zakresie remontu silników, a przez to brak dostępu do zmieniających się strategii eksploatacyjnych silników, implikuje poważne problemy w zarządzaniu eksploatacją silników RD-33. Obniżający się potencjał eksploatacyjny silników spowodowany brakiem jego normowania powoduje poważne problemy eksploatacyjne, które w przyszłości będą musiały być poddane przeobrażeniom w wyniku zdecydowanych działań zarządczych.

\section{Bibliography/Literatura}

[1] Boguszewicz P., Sala S. Bird strike, czyli zderzenie z ptakiem. Prace Instytutu Lotnictwa 213, s. 101-111, Warszawa 2011.

Maciej Trelka - Commander of 23rd Airbase, Mińsk Mazowiecki.

Plk dypl. pil. inż. Maciej Trelka - dowódca 23. Bazy Lotnictwa Taktycznego w Mińsku Mazowieckim/ e-mail: 23blt@wp.mil.pl

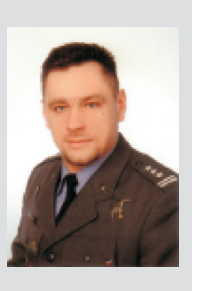

Jarosław Bartoszewicz, DSc. DEng. - professor in the Chair of Thermal Engineering, Poznań University of Technology.

Dr hab. inż. Jarostaw Bartoszewicz, prof. PP-profesor na Wydziale Maszyn Roboczych i Transportu Politechniki Poznańskiej.

e-mail: Jaroslaw.Bartoszewicz@put.poznan.pl
[2] Dudziński A., Dudzińska A., Michalska M. Raport nr 5a/36/2014 z badań uszkodzeń łopatek turbiny WC silnika RD33 nr 870881972265. Instytut Techniczny Wojsk Lotniczych, Warszawa 2014.

[3] Kozakiewicz A. Analiza uszkodzeń turbinowych silników odrzutowych. Prace Instytutu Lotnictwa 213, s. 224-234, Warszawa 2011.

[4] Sarnecki J., Dzięgielewski W., Gawron B. Sprawozdanie z pracy nr 20/55/2011 pt. Badania przyczyn nadmiernego nagarowania wtryskiwaczy silników RD-33 i AŁ-21F3 - Etap I. Instytut Techniczny Wojsk Lotniczych, Warszawa 2011.

Rafał Urbaniak, DEng. - doctor in the Faculty of Machines and Transport at Poznan University of Technology.

Dr inż. Rafat Urbaniak - adiunkt na Wydziale Maszyn Roboczych i Transportu Politechniki Poznańskiej. e-mail:rafal.urbaniak@put.poznan.pl

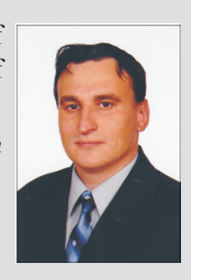

